\title{
3D models related to the publication: Siphonodella leiosa (Conodonta), a new unornamented species from the Tournaisian (lower Carboniferous) of Puech de la Suque (Montagne Noire, France).
}

\author{
Souquet Louise ${ }^{1,2 *}$, Corradini Carlo ${ }^{3}$, Girard Catherine ${ }^{4}$ \\ ${ }^{1}$ Institut de Génomique Fonctionnelle de Lyon, ENS de Lyon, UMR 5242, CNRS, Université Claude Bernard Lyon 1, 46 allée d'Italie, Lyon Cedex 07, \\ France \\ ${ }^{2}$ Current address: Centre de Recherche en Paléontologie - Paris, UMR 7207, CNRS, CP 38, Muséum National d'Histoire Naturelle, 75005 Paris, \\ France \\ ${ }^{3}$ Dipartimento di Matematica e Geoscienze, Università di Trieste, via Weiss 2, 34128 Trieste, Italy \\ ${ }^{4}$ ISEM, Univ Montpellier, CNRS, EPHE, IRD, Montpellier, France \\ *Corresponding author: louise.souquet@mnhn.fr
}

\begin{abstract}

$\begin{array}{lll}\text { Model IDs } & \text { Status } & \text { Description } \\ \text { UM PSQ 1 } & \text { Paratype } & \text { Dextral P1 element } \\ \text { UM PSQ 2 } & \text { Holotype } & \text { Dextral P1 element } \\ \text { UM PSQ 3 } & \text { Paratype } & \text { Dextral P1 element } \\ \text { UM PSQ 4 } & \text { Paratype } & \text { Dextral P1 element } \\ \text { UM PSQ 5 } & \text { Paratype } & \text { Sinistral P1 element } \\ \text { UM PSQ 6 } & \text { Paratype } & \text { Dextral P1 element } \\ \text { UM PSQ 7 } & \text { Paratype } & \text { Dextral P1 element } \\ \text { UM PSQ 8 } & \text { Paratype } & \text { Sinistral P1 element } \\ \text { UM PSQ 9 } & \text { Paratype } & \text { Dextral P1 element }\end{array}$
\end{abstract}

The present 3D Dataset contains the 3D models of the holotype and the paratypes of the new species Siphonodella leiosa described and analyzed in the following publication: L. Souquet, C. Corradini, C. Girard: Siphonodella leiosa (Conodonta), a new unornamented species from the Tournaisian (lower Carboniferous) of Puech de la Suque (Montagne Noire, France). Geobios, https://doi.org/10.1016/j.geobios.2020.06.004.

Keywords: Carboniferous, Conodonts, Holotype, Montagne Noire, Siphonodella

Submitted:2020-03-26, published online:2020-07-21. https://doi.org/10.18563/journal.m3.115
Table 1. 3D models of the holotype and paratypes of Siphonodella leiosa. Collection: University of Montpellier, France

\section{INTRODUCTION}

Siphonodella leiosa is a new species of conodont described in our paper entitled "Siphonodella leiosa (Conodonta), a new unornamented species from the Tournaisian (lower Carboniferous) of Puech de la Suque (Montagne Noire, France)" based on a set of P1 buccal elements. The specificity of this species compared to other Siphonodella is its unornamented platform. This new discovery reinforces the idea that ornamentation of siphonodellids is related to bathymetry, but also to sea-surface temperature. We discuss the ecological and environmental significance of this new taxon. The 3D models of the holotype (UM PSQ 2) and the paratypes are provided here (Table 1, Fig.1).

\section{METHODS}

Digitization of the specimens was performed using an X-ray microtomograph $(\mu \mathrm{CT})$ Phoenix nanotomeS on the AniRA-Immos platform of the SFR Biosciences (UMS 3444, ENS Lyon) at a cubic voxel resolution of $1 \mu \mathrm{m}$. The 3D surfaces were extracted semi-automatically within AVIZO 6.3.0 (FEI) using the segmentation threshold selection tool. The 3D surfaces are provided in .ply format, and can therefore be opened with a wide range of freeware.

\section{ACKNOWLEDGEMENTS}

We acknowledge the contribution of SFR Biosciences (UMS3444/ CNRS, US8/ Inserm, ENS de Lyon, UCBL) AniRa-ImmOs facility. We particularly thank Mathilde Bouchet for her kind assistance during the scanning sessions. The research was supported by the Project Marcon (Labex CeMEB). This is contribution ISEM 2020-143.

\section{BIBLIOGRAPHY}

Souquet L., Corradini C., Girard C., 2020. Siphonodella leiosa (Conodonta), a new unornamented species from the Tournaisian (lower Carboniferous) of Puech de la Suque (Montagne Noire, France). Geobios, https://doi.org/10.1016/j.geobios.2020.06 .004 . 


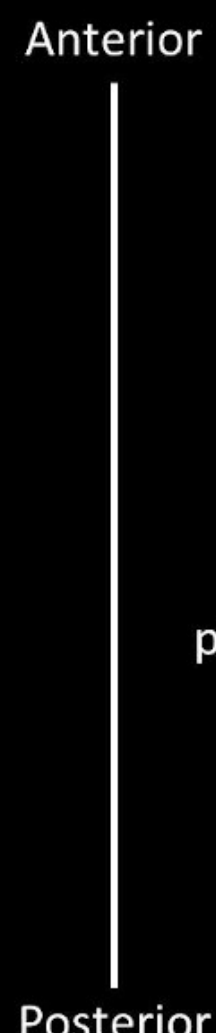

Posterior

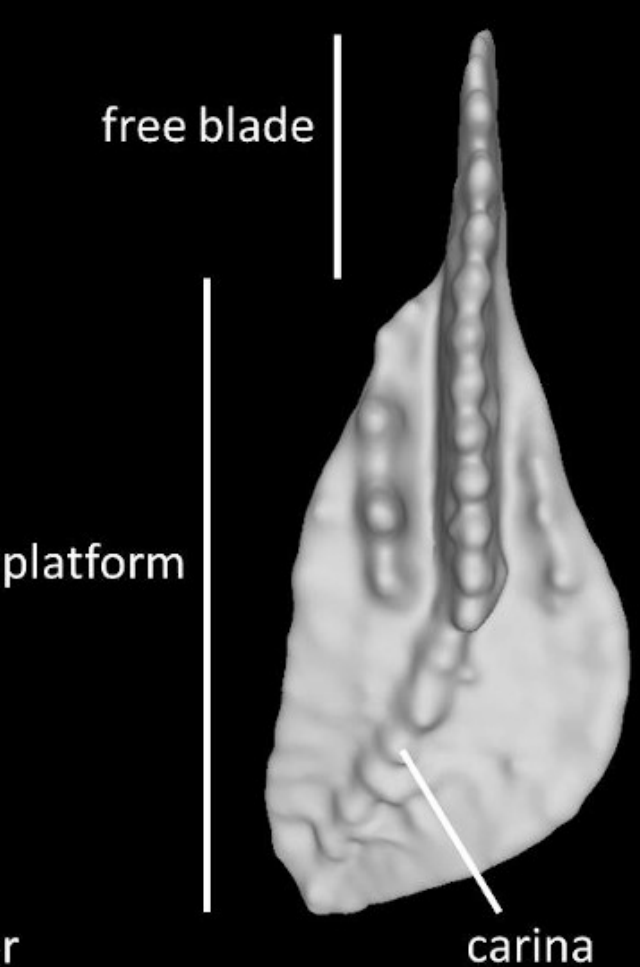

carina

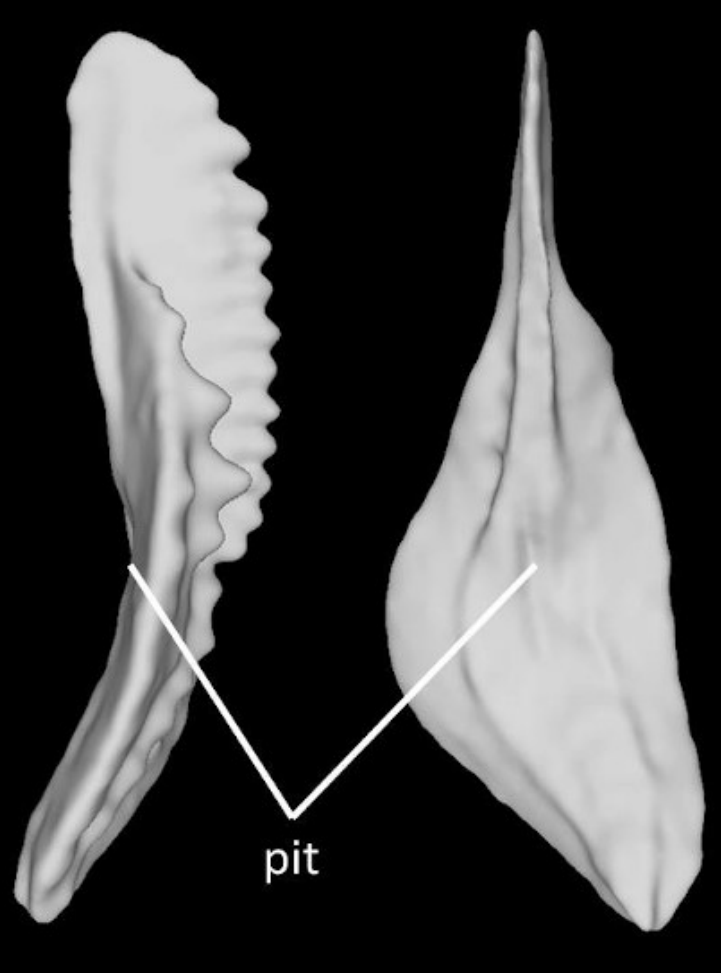

$500 \mu \mathrm{m}$

Figure 1. Siphonodella leiosa, new species. Holotype (UM PSQ 2). From left to right: upper (oral), lateral and lower (aboral) views of P1 element. 